\title{
As crianças no encontro com o outro: uma perspectiva relacional e afetiva da responsabilidade
}

\section{Children within the encounter with the other: a relational and affection perspective over responsibility}

Juliana Siqueira de Lara ${ }^{1}$

Lucia Rabello de Castro²

Resumo: O presente trabalho discute como a responsabilidade pelo outro é significada nas experiências intersubjetivas do cotidiano de crianças moradoras de uma comunidade localizada na cidade do Rio de Janeiro, sudeste do Brasil. Partindo de uma problematização da normatividade que a noção de responsabilidade adquire nos estudos da infância, investigou-se em uma pesquisa de campo de caráter etnográfico com crianças de 4 a 13 anos de idade, como a dimensão relacional e afetiva da responsabilidade se apresenta no cotidiano. Os resultados encontrados mostram que as crianças são responsáveis pelo outro que as interpela afetivamente, quando a sua participação ativa se revela no âmbito do cuidado fraterno, da manutenção de seus lares e das posições de ajuda e proteção frente a outras pessoas com quem puderam compartilhar suas experiências.

Palavras-chave: Infância; Responsabilidade; Alteridade; Cuidado; Participação Social.

Abstract: The present work discusses how responsibility for somebody else is construed in the intersubjective experiences of the daily life of children living in a poor community located in the city of Rio de Janeiro,

1 Instituto de Psicologia - Universidade Federal do Rio de Janeiro. E-mail: j.siq.lara@gmail.com.

2 Mestra em Psicologia pelo Programa de Pós Graduação em Psicologia da Univserdidade Federal do Rio de Janeiro. Endereço eletrônico: j.siq.lara@gmail.com

Latitude, Vol. 10, no 2, pp. 217-249, 2016

DOI: https://doi.org/10.28998/2179-5428.20160204 
As crianças no encontro com o outro: uma perspectiva relacional e afetiva da responsabilidade

southeastern Brazil. The normative dimension of the notion of responsibility is problematized within the field of childhood studies, as the present investigation, based on an ethnographic approach with children of 4 to 13 years of age, takes into account its relational and affective dimension present in the daily life of children.. The results show that children felt responsible for those whom they were affectively related, inasmuch as.their active participation could be shown as fraternal care, in the daily tasks for the upkeeping of their homes and as a commitment to help and protect others with whom they shared their everyday experiences.

Keywords: Childhood; Responsibility; Alterity; Care; Social Participation.

\section{Introdução}

O campo de estudos da infância passou nas últimas décadas por importantes transformações produzindo novos olhares e debates acerca das questões que atravessam a vida das crianças. Este movimento de teorização e pesquisa proposto mais recentemente se insere no âmbito de um contexto histórico político e social de mudanças em nível global, no qual os sujeitos infantis passam por novas formas de subjetivação que incluem o surgimento de seus direitos e, consequentemente, diferentes posições de troca entre gerações.

Frente a tais processos de mudança, alguns aspectos que embasam os lugares sociais que esses sujeitos devem ocupar têm se tornado objeto de estudo de diferentes pesquisadore/as. Dentre eles, cita-se a responsabilidade, que por muito tempo esteve atrelada única e exclusivamente a adultidade, e que, cada vez mais, torna-se um "conceito chave" nas discussões públicas e políticas acerca da infância e das crianças, pois se considera que ela problematiza as definições de infância moderna e de diferença geracional construídas tradicionalmente (Such and Walker, 2004; Morrow, 2008).

Este trabalho toma como objeto de estudo mais amplo a temática da responsabilidade e sua aproximação com a infância, partindo de uma visão crítica em relação ao entendimento tácito que esta noção adquiriu, e propondo uma perspectiva relacional e afetiva da mesma. A partir dos resultados de uma pesquisa de campo de caráter etnográfico realizada em 
uma comunidade da cidade do Rio de Janeiro, sudeste do Brasil ${ }^{3}$, pretendese refletir como a responsabilidade pelo outro é significada nas experiências intersubjetivas do cotidiano de crianças a partir das posições que assumem frente às necessidades e vulnerabilidades que o outro lhes apresenta.

\section{A responsabilidade individual da criança no âmbito dos Novos Estudos da Infância}

As teorias psicológicas do desenvolvimento humano e da socialização clássica associaram, respectivamente, a responsabilidade à ideia de maturidade apontando a relevância dos processos sociais que normatizam e institucionalizam a sua aquisição da infância à vida adulta. Assim, as crianças ainda seriam incapazes de assumirem responsabilidades, e/ou seriam consideradas irresponsáveis, sendo os adultos, estes sim, os detentores de responsabilidades e/ou indivíduos considerados responsáveis.

Atualmente, com o intuito de desconstruir a obviedade e legitimidade presentes em tais paradigmas tradicionais da infância como fase natural e universal da vida e das crianças como objetos passivos de socialização numa ordem social adulta (James et Prout 2015 [1997]), posições teóricas assumidas especialmente por autores alinhados aos Novos Estudos da Infância defendem que crianças que exercitam a responsabilidade desafiam a ordem social. Nesta as crianças são consideradas como devires humanos e os adultos vistos como tendo o controle legítimo sobre elas (Qvortrup, 1994).

A emergência de se considerar a criança enquanto um indivíduo responsável repousa sobre o questionamento de sua imagem até então naturalizada enquanto um ser imaturo, vulnerável, incapaz e cuja proteção seria o único direito a lhe ser assegurado. A expectativa é ir contra a ideia de que os direitos das crianças não são aceitáveis, porque elas não podem assumir as responsabilidades que estão relacionadas a tais direitos

\footnotetext{
${ }^{3}$ Pesquisa fruto da dissertação de Mestrado "A responsabilidade no encontro com o outro: uma aposta ética a partir da infância", defendida em Maio de 2016 e vinculada ao Programa de Pós Graduação em Psicologia, da Universidade Federal do Rio de Janeiro. Teve apoio para seu desenvolvimento da Coordenação de Aperfeiçoamento de Pessoal de Nível Superior (CAPES).
} 
As crianças no encontro com o outro: uma perspectiva relacional e afetiva da responsabilidade

(Flekkøy et Kaufman, 1997) e apostar na responsabilidade como uma variável importante que permite às crianças uma maior participação social diante da comunidade (Keating, 2008).

Such and Walker (2004) destacam três vertentes nos novos estudos da infância que, em parte, desconstroem a relação entre a responsabilidade e a infância moderna: estudos sobre o trabalho infantil, investigações sobre a negociação da vida diária e aqueles que exploram o estatuto moral das crianças e sua agência. A discussão desses estudos repousa, de forma geral, sobre a afirmação da competência, da autonomia e da independência das crianças na realização de atividades, contribuindo para a percepção de que as crianças que respondem de forma satisfatória às normas sociais devem ser consideradas como "boas cidadãs", "bons filhos/as", "boas alunas" etc.

Ao analisar conceitualmente a noção de responsabilidade, vemos, assim como confirma O'Brian Jr (2009), que a sua definição precisa não se mantém clara no âmbito dos estudos que se debruçam sobre o tema na infância. Entretanto, destacamos que as ideias de dever e obrigação são amplamente utilizadas em associação a esta noção. Brobbey (2011), por exemplo, utiliza a seguinte conceituação para embasar a sua posição: "[A responsabilidade é] um dever que você tem que fazer, porque é parte de seu encargo ou posição" e "sendo encarregado de alguém ou de alguma coisa, deve se certificar de que o que fazem ou o que acontece com eles é certo ou satisfatório" (Idem, p. 38) (Tradução nossa).

O conceito de responsabilidade ligado à noção de dever é correlato ao âmbito jurídico, que pressupõe um princípio de organização que faz referência ao dever de cada um de responder por seus atos e decisões (Berti, 2008). Por exigência da convivência social, o direito positivo impõe conduta às pessoas na forma do dever jurídico. Caso a violação de tal dever acarrete um dano para outrem este gera uma nova obrigação, qual seja, o de reparar o dano. No sentido jurídico, a responsabilidade civil designa o dever que alguém tem de reparar o prejuízo decorrente da violação de uma obrigação descumprida (Cavalieri Filho, 2012).

Dessa forma, o sistema jurídico engendra formas de regular e constranger a vida dos indivíduos e, mais do que isso, produz modos de subjetivação que os inserem na ordem constitucional do que é permitido ou proibido na relação com outros seres humanos (Castro, 2013). Progressivamente, as crianças, bem como os adultos, estão submetidas a 
regulações jurídicas que criam modos de ser e estar no mundo com outras pessoas na conquista de direitos e privilégios legais. Argumenta-se aqui que o entendimento jurídico que fundamenta a responsabilidade como um dever parece modelar percepções de ação e resposta ao outro, podendo obscurecer outros modos de pactuar a convivência entre as pessoas (Idem).

Destaca-se também que este entendimento é embasado pela construção de um modelo subjetivo associado às capacidades de auto regulação e autonomia como atributos do indivíduo racional, consciente de suas ações e capaz de responder por elas, uma vez que são as suas capacidades intelectuais, as suas intenções e as razões de suas ações que aparecem como critérios para o julgamento da responsabilidade. É a capacidade, o julgamento reflexivo, o poder e a autonomia que se apresentam como atributos essenciais para se argumentar a responsabilidade individual da criança (Such and Walker, 2004; Bjerk, 2008).

Nós compreendemos que a construção da noção de responsabilidade da criança e da sua representação enquanto um indivíduo responsável no contemporâneo segue a tendência que reconfigurou o campo dos direitos e passou a considerar a criança como uma cidadã, tentando inscrevê-la numa relação de igualdade em relação ao adulto. A Convenção Internacional sobre os Direitos das Crianças, proposta em 1989, reconhece os sujeitos infantis com direitos e liberdades que até então eram destinados apenas aos mais velhos.

Entretanto, neste trabalho nós partimos de uma dupla problematização do entendimento da responsabilidade estreitamente ligada a um dever individual a ser cumprido. Primeiramente, os atributos apresentados por esta compreensão sobre responsabilidade presumem uma subjetividade centrada na supremacia do eu em detrimento do outro. Dessa forma, os enfrentamentos entre os indivíduos, as interpelações afetivas, as cooperações possíveis e o próprio reconhecimento da alteridade ficam relegados a um segundo plano, uma vez que é a autonomia individual e racional que se destaca enquanto uma primazia a ser ressaltada na criança.

Em segundo lugar, ainda que os estudos da infância mais recentes reconheçam o papel ativo e produtor que as crianças e jovens assumem nos processos de transmissão cultural (James et Prout, 2015 [1990], Qvortrup, 1994, entre outros), de forma geral, a ênfase permanece nas aptidões que 
As crianças no encontro com o outro: uma perspectiva relacional e afetiva da responsabilidade

devem aparecer, e como tais aptidões dizem respeito ao funcionamento do que já está instituído: "a sociedade dos adultos e suas instituições" (Castro, 2009 , p.482). Dessa forma, coloca-se em questão a posição assumida pelas crianças tendo como única e exclusiva referencia a subjetividade adulta ideal e não a sua posicionalidade a partir de outros referenciais, como os das próprias crianças na relação com os seus pares. (Idem).

Diante de tais dificuldades, questionamos neste trabalho se é possível pensar a posição social da criança hoje sem levar em consideração a importância das interações e constrangimentos vividos na própria relação com o outro. Na medida em que o indivíduo assume a responsabilidade como circunscrita e afirmada em si próprio a partir de normas e prescrições, o outro tende a ser objetificado frente à soberania das leis Problematizamos, assim, a consideração de uma subjetividade infantil fechada em si mesma e dotada de uma racionalidade plena, assim como se espera do constructo do adulto ideal, que dê conta daquilo que é vivido na experiência intersubjetiva e diz respeito à própria construção da vida em sociedade.

\section{A responsabilidade pelo outro: uma aposta afetiva e relacional de cuidado}

Como forma de lançar mão de uma proposta que nos permita flexionar as problemáticas expostas, nós nos inspiramos na perspectiva teórica de Emmanuel Levinas acerca da responsabilidade. Gostaríamos de pensar a responsabilidade enquanto um posicionamento a uma demanda do outro, um chamamento, que convoca o sujeito à uma experiência ética (Levinas, 1980).

A responsabilidade por essa perspectiva é anterior à relação lançada no sentido jurídico, uma vez que não pressupõe o caráter autonômico do sujeito e a sua capacidade de controle implicada no julgamento de sua ação. a $\mathrm{O}$ seu caráter heteronômico sustenta o seu sentido ético, e não o autonômico da moral (Farias, 2012). Dessa forma, o sujeito é marcado por uma experiência de "hetero-afetividade", (Critchley, 2008, p. 62), sendo os sentimentos, impulsos, inclinações e afetamentos fundamentais a responsabilidade.

Mais do que esperar que o agir responsável seja resultado da autonomia do indivíduo racional, a teoria de Levinas nos permite apostar 
na existência de uma subjetividade ética, cuja constituição se dá por um ato de aprovação a uma demanda que é fundamentalmente inadequada, uma vez que no encontro com o outro e suas diferenças, as demandas expostas nunca são plenamente respondidas. É essa inadequação que explica porque, para Levinas, a relação com o outro é assimétrica, pois o sujeito se relaciona com algo que excede sua capacidade de compreensão (Idem).

O cuidado é apresentado na literatura como o cerne da compreensão de responsabilidade neste sentido que estamos trazendo aqui. Molinier et Paperman (2015) nos dizem que as variadas relações de cuidado constantemente compreendem tensões e conflitos, assim como a concepção da responsabilidade por uma perspectiva relacional supõe que as relações sejam sempre parciais, distendidas, múltiplas, mutáveis, conflituosas, assimétricas, entre diferentes tipos de protagonistas, em variados níveis.

Colonna (2012) em estudo realizado com crianças moçambicanas demonstra que o cuidado de crianças com seus irmãos e irmãs é uma "responsabilidade fundamental" (Idem, p. 268). Através de alguns dos episódios apresentados pela autora, através de seu convívio com elas, é possível vislumbrar que cuidar de crianças é muito mais do que simplesmente fazer coisas, como deveres e tarefas a serem cumpridas satisfatoriamente, uma vez que se constroem complexas relações sociais, não apenas de cuidado, mas também de afeto, de amizade e de poder, frequentemente marcadas por negociações e disputas entre crianças cuidadas e cuidadoras.

No estudo de Morrow (2008), que se baseia em dados gerados em três projetos de pesquisa com crianças em idade escolar, na Inglaterra, a autora também associa a responsabilidade ao cuidado que as crianças, especialmente as meninas, assumem com crianças fora de suas famílias nas atividades de babysitting. $\mathrm{O}$ fato de ser considerada uma forma de trabalho pelas crianças, por sua característica remunerada, não elimina os aspectos relacionais e afetivos evocados pelo encontro que as crianças cuidadoras mantêm com outras crianças.

É possível argumentar que as crianças que cuidam de outras crianças possuem simbolica e socialmente (mas não legalmente) um papel de extrema importância, assim como o pai e mãe possuem, por um período de tempo. "Ser uma babá significa que você tem a vida de alguém em sua mão e que, em si, é uma tremenda responsabilidade [...]" (RoSPA, 2004 
As crianças no encontro com o outro: uma perspectiva relacional e afetiva da responsabilidade

apud Idem, p. 115). Além disso, o estudo do cuidado com o outro aponta a noção de confiança como fundamental à responsabilidade, uma vez que confiar envolveria colocar um bem precioso em poder de outra pessoa e, assim, correr um grande risco por isso (Idem).

Nesse sentido, partilhamos do que nos diz a autora de que poderíamos usar a responsabilidade no âmbito das práticas da vida familiar para explorarmos uma abordagem mais diferenciada das relações, dando mais atenção à reciprocidade e a confiança entre aqueles que fazem parte da vida cotidiana das crianças. $O$ alto valor colocado no individualismo e na independência da vida adulta nas sociedades ocidentais, muitas vezes mascara a interdependência própria das relações sociais (Idem), importantes para a construção da humanidade.

Neste trabalho, nós nos interessamos em investigar como a responsabilidade pelo outro, inspirada na teoria ética de Emmanuel Levinas, qualifica-se nas relações intersubjetivas do cotidiano infantil. Ao tomarmos esta perspectiva da responsabilidade, nós pretendemos refletir sobre as posições das crianças diante da interpelação que formas diferentes de existência que não as suas lhe fazem sem que o aparato legislativo baseado em princípios autonômicos e racionais exerça algum controle sobre tal prática.

\section{Perspectivas investigativas e escolhas metodológicas}

Este trabalho é fruto de uma pesquisa de cunho qualitativo e que parte da compreensão de que o/a pesquisador/a intervém naquilo que está pesquisando e os sujeitos participantes, entendidos por nós como agentes e detentores de um saber, produzem juntos com o/a pesquisador/a uma interface no processo e no desenvolvimento da investigação (Castro et Besset, 2008).

Tratando-se de uma pesquisa com crianças e cuja pesquisadora do trabalho de campo foi uma adulta, a posição assumida por nós de compreender as crianças como sujeitos e não como objetos de estudo, marca a nossa visão de que as crianças em si mesmas são entendidas como sujeitos ativos na sociedade em que estão inseridas e seus saberes, afeições e valores são levados em conta no caminhar de toda a investigação.

Nesse sentido, nós buscamos realizar as nossas escolhas metodológicas com o intuito de nos aproximar ao máximo do que dizem, 
sentem e vivem as crianças e, por isso, elegemos a etnografia, cujo método que se destaca é a observação participante, como um dos recursos que oportuniza e privilegia esta aproximação (James, 2001).

A pesquisa de campo do nosso trabalho ocorreu durante três meses do ano de 2015 em uma escola pública situada em uma comunidade de baixa renda da zona portuária da cidade do Rio de Janeiro, além de locais e trajetos que as crianças frequentavam de suas casas até a escola e vice versa. Os resultados analisados neste artigo são fruto da utilização da observação-participante, com anotações em diários de campo, com crianças em idade escolar de 4 a 13 anos. ${ }^{4}$

A utilização deste método possibilitou uma aproximação do cotidiano das crianças na escola, principalmente através do convívio com elas em suas brincadeiras e jogos durante o horário do recreio, e de suas realidades para além dos muros da escola, pelos locais em que transitavam e moravam. A observação participante oportunizou que estabelecêssemos com as crianças uma relação de confiança, afeição e respeito recíprocos, contribuindo também, para que captássemos as suas ações e discursos em ato (Goldman, 2003).

Com isso, pudemos compartilhar com elas de momentos de interação com seus/suas irmão/ãs, seus pares, professoras/es, mães e também apreender as suas posições diante da pesquisadora do trabalho de campo. De acordo com Castanheira et al (2001), observando as falas e as ações das crianças, os momentos e lugares em que ocorrem, os significados que assumem, os artefatos que são utilizados, as implicações para o grupo de que fazem parte, é possível que o/a pesquisador/a identifique os conhecimentos e as práticas que os sujeitos constroem e utilizam para interpretar a própria experiência e gerar ações sobre o mundo.

As anotações dos diários de campo produzidos a partir da observação-participante geraram o material que foi transcrito e narrado na primeira pessoa do singular nesta escrita, conforme a inserção no campo da primeira autora deste trabalho. A seguir, propomos a discussão de alguns dos resultados produzidos, em que o modo como as crianças se posicionaram para com o outro - um membro familiar, como irmãs, mãe e

\footnotetext{
${ }^{4}$ A pesquisa de campo mencionada também utilizou o método dos grupos-focais (Morgan et Spanish, 1984), cujos resultados encontrados não entraram nas análises do presente trabalho por uma questão de espaço.
} 
As crianças no encontro com o outro: uma perspectiva relacional e afetiva da responsabilidade

pai, como também, alguém menos familiar, como a pesquisadora do trabalho de campo e seus colegas na escola - é analisado.

\section{A responsabilidade pelo outro nas experiências intersubjetivas do cotidiano infantil}

\section{1 "Eu cuido dela como se ela tivesse saído de dentro mim": experiências de cuidado entre irmãs}

A escola na qual nos inserimos era caracterizada pela presença de muitos irmãos/ãs. Alguns com idades próximas, outros com idades mais distantes, irmãos homens, irmãs mulheres, casais, trios, cada fratria com uma configuração diferente. Durante a observação participante, as experiências de cuidado especialmente entre irmãs se apresentaram como comuns no cotidiano das crianças.

A primeira relação fraterna com a qual eu tive contato foi a de Jaqueline, Gisele e Julia, respectivamente de 12 anos, 9 anos e de 6 anos. Ao me aproximar desta relação, eu descobri que a irmã mais velha é quem, pelos pais, é designada a levar e trazer as mais novas para escola, e também, em casa, no período da tarde, quem esquenta para elas a comida do almoço já deixada pela mãe e as ajuda nas tarefas de casa. Em um dos dias que acompanhei as irmãs na direção de sua casa, eu fui conversando com a Jaqueline, a irmã mais velha, que carregava a mochila da irmã caçula nas costas, sobre o que ela achava de levar as irmãs para a casa.

Eu: Jaqueline, eu já vi algumas vezes vocês indo pra casa juntas sem a companhia de nenhum adulto... Isso é comum?

J: É, porque nossos pais trabalham de tarde, aí eu que tenho que levar elas pra casa.

Eu: Ah, entendi... E o que você acha de ter que levá-las pra casa?

$\mathrm{J}:$ Chato!! (risos)

Eu: Chato? Por quê?

$\mathrm{J}$ : Por que elas não me obedecem, não querem andar nas calçadas, aí vão pro meio da rua.

Eu: E o que pode acontecer se elas forem pro meio da rua? 


\section{J: Aí elas podem se machucar, é perigoso pra elas. Eu: E se elas se machucarem, o que acontece? $\mathrm{J}:$ Ah, tia, é horrível, né? (risos) \\ Eu: Como assim "é horrível"? \\ $\mathrm{J}$ : Ah, tia, eu não gosto que elas se machuquem, né? \\ Eu: E por que não? \\ $\mathrm{J}$ : Ué, porque elas são minhas irmãs! e, em seguida, coloca as mãos para na cintura, como se estivesse falando uma obviedade para mim. (Diário de Campo, Setembro, 2015)}

Primeiramente, a conversa com Jaqueline demonstra que ela assume a posição de cuidadora porque os seus pais estariam trabalhando e, portanto, não poderiam buscá-las na escola e prover alguns cuidados em casa no período da tarde. Em seguida, vemos que para a menina, levar as irmãs para a casa se apresenta como uma obrigação, pelo uso da expressão "ter que" e também nos diz que essa é uma prática que ela considera "chata". De fato, atividades qualificadas como responsabilidades, incluindo as práticas de cuidado entre crianças, dependendo das circunstâncias, são vivenciadas pelas crianças tanto como um privilégio quanto como um fardo (Bjerke, 2011).

Entretanto, os risos apresentados pela menina durante as suas respostas parecem evocar uma ambiguidade nesse fardo. $O$ fato de ser a criança delegada a cuidar de suas irmãs pode lhe conceder um lugar de satisfação e poder, na medida em que se coloca como a irmã que manda, enquanto as outras a obedecem e também em um lugar em que a confiança (Morrow, 2008) se destaca na relação de seus pais para com ela.

Além disso, ao questionar a menina acerca da justificativa para tal atribuição "chata", ela revelou que assim o era porque, no final das contas, caso as irmãs não a obedecessem, elas poderiam ir para o meio da rua e se machucarem. Assim, o que se apresenta como "chata" parece ser a possibilidade das irmãs mais novas estarem correndo algum perigo e ela não ter o total controle sobre isso. O desejo de Jaqueline, de que as suas irmãs não se machuquem, é perpassado pelas imprevisibilidades do trajeto para a casa que inclui, também, as vontades das irmãs de irem pro meio da rua. Desse modo, parece que a tarefa de levar as irmãs pra casa está atravessada por riscos que a própria prática de cuidado impõe (Idem). 


\section{As crianças no encontro com o outro: uma perspectiva relacional e afetiva da responsabilidade}

Outro vínculo entre irmãs na qual eu me aproximei, que também parece estar atravessado por manifestações de cuidado e proteção, foi a de Mel e Evelyn, de 7 e 6 anos respectivamente. As irmãs moravam em uma das ruas principais da comunidade e dividiam a casa com seus pais e a avó. Em um dos dias que conversávamos bastante na escola, Mel perguntou se eu poderia ir com ela e a irmã até na frente de sua casa, para me mostrar onde era:

Na hora da saída, Mel se aproximou de mim para irmos embora juntas, mas antes, nós tínhamos que buscar a irmã mais nova na sala de aula. Ao chegar à porta da sala, a professora chamou a Evelyn, que estava aguardando a irmã, e disse para a Mel, em tom enfático e com o dedo indicador balançado: "Olha, Mel, eu não quero ver a sua irmã trazendo e comendo biscoito na sala de aula, entendeu!?". Mel abaixou os olhos e fez sinal que 'sim' com a cabeça. Quando a Evelyn saiu da sala, Mel colocou um dos braços em volta do pescoço da irmã mais nova e perguntou baixinho pra ela: "Você levou anotação na agenda?". Evelyn respondeu também baixinho: "Não, não tem nada". E então, Mel falou: "Menos mal, porque se não eu não teria como te salvar para a mamãe". Seguimos caminhando de mãos dadas e assim que saímos do pátio, Mel e Evelyn abriram a mochila, tiraram seus biscoitos e começaram a comer. Na hora de sair da calçada, de forma muito rápida e inesperada por mim, Mel colocou o braço na frente do corpo de Evelyn e com um biscoito na boca disse alto: "Evelyn, espera! O carro está vindo!!". Havia um carro ainda distante entrando na rua, mas a menina quis se antecipar, parecendo querer precaver a irmã de um possível atropelamento. Esperamos o carro passar e atravessamos a rua. Enquanto andávamos, a menina mais nova contou, em tom queixoso, sobre o ocorrido na sala de aula, que tinha sido um colega quem abriu o biscoito e o distribuiu pras outras crianças e não ela. Logo em seguida, como se quisesse acalmar a irmã, Mel disse: "Se não tem anotação na agenda, não tem problema, não vou contar nada pra 
mamãe". Diante da resposta dela, eu a questionei: "E por que você não conta pra sua mãe sobre o que houve com a Evelyn, Mel?". E a menina respondeu: "Porque ela é minha irmã e eu tenho que proteger ela". "E por que você tem que proteger ela?", eu a indaguei curiosa. Ela disse: "Porque eu gosto dela e não gosto de ver ela de castigo. Se ela fica de castigo, ela fica triste e eu também não tenho com quem brincar". (Diário de Campo, Novembro, 2015)

Este extrato de nosso diário de campo nos aponta primeiramente que, para a professora, a Mel é a pessoa que deveria orientar a Evelyn sobre o seu comportamento com biscoitos em sala de aula. Para a menina, que acata com os olhos o que a professora diz, entretanto, o mais importante é proteger a irmã. Esta constatação pôde ser apreendida a partir do desenrolar da situação em que Mel em nenhum momento repreende a irmã ou a aconselha sobre como agir na sala de aula em relação ao seu biscoito demonstrando como a relação com a sua irmã é atravessada por grande afeição e pela ideia de proteção. Constatamos isso em duas ações descritas neste extrato, o de proteger a irmã mais nova dos perigos da rua, com o alerta do carro que vinha em nossa direção, ainda que distante, e também em relação a "salvar a irmã" dos castigos da mãe.

Nesse sentido, a menina pareceu privilegiar o fato da irmã não ficar de castigo ao fato de sua mãe ficar sabendo do ocorrido na escola. A justificativa dada por ela para esta escolha passa pela possibilidade de a irmã mais nova se entristecer, algo que ela pareceu não gostar, e também porque ficando de castigo, a Mel não teria com quem brincar. Sobre isso, o estudo de Colonna (2012) também apontou que as crianças mais velhas estabelecem uma relação de cumplicidade com as mais novas, suspendendo temporariamente o seu papel de cuidadoras e responsáveis na visão dos adultos, para estarem juntas a favor de alguma coisa que os mais velhos não aprovariam. Nestes casos, trata-se de relações de maior horizontalidade, onde a identificação como crianças prevalece em contraposição àquela do mundo dos adultos (Idem).

Ao nos aproximarmos de outras situações que atravessaram esta relação, pudemos identificar a posição de importância que a irmã mais nova ocupa para a irmã mais velha. Em uma das idas em direção a sua 
As crianças no encontro com o outro: uma perspectiva relacional e afetiva da responsabilidade

casa, em que estávamos inseridas em um grupo com mais crianças, Mel andava de mãos dadas comigo e sua irmã estava mais atrás com outras colegas. Ao avistar a sua casa, a menina perguntou em voz alta, olhando para trás: "Cadê a minha filha?". Surpresa com a pergunta, eu a questionei: "Filha?". E ela respondeu rindo: "É a minha irmã, mas é como se fosse a minha filha, tia!". "Como assim, Mel?, eu perguntei. E ela me respondeu: "Ah, é porque eu cuido dela como se ela tivesse saído de dentro de mim", e, em seguida, largou a minha mão para dar a mão para a irmã.

Esta fala da Mel parece apontar para o quão próxima parece ser esta relação, uma vez que a menina se coloca em uma posição maternal perante a irmã que é tomada como uma "parte" que saiu dela. Frente à ausência dos pais e mães, é comum o/a irmão/ã mais velho/a assumir a posição parental de cuidados e afetos destinados a criança mais nova da família (Carreño et Ávila, 2002).

Ressaltamos também que o fato de Mel ser mais velha que Evelyn não parece cristalizar as posições assumidas pelas irmãs nessa relação. Ainda que tenhamos visto com o extrato anterior que, para Mel, a irmã mais nova é como se fosse a sua filha, foi possível apreender que ambas realizavam o que elas chamaram de "ajuda" de uma para com a outra. Foi verificado que as irmãs entendem por "ajuda" as práticas de elaborar um penteado no cabelo, esquentar a comida, ajudar no dever de casa e também em arrumar o quarto. Essas práticas eram exercidas uma para com a outra e vice versa, apontando que a ajuda não era praticada em uma via única $\mathrm{e}$ sim, mutuamente..

A terceira relação que traremos como exemplo em nosso estudo é de mais três irmãs as quais nos aproximamos: Adrielly, Ana e Danielle, de 6, 8 e 10 anos, respectivamente. Assim como as relações fraternas anteriores, as três irmãs iam para a casa sem a companhia de nenhum adulto. A mãe e o padrasto das meninas não estavam em casa quando estas voltavam da escola.

Foi possível apreender que demonstrações de cuidado e proteção atravessavam esta relação, assim como a existência de companheirismo, solidariedade e empatia. Parece-nos importante salientar, entretanto, que, ainda que a relação seja perpassada por afeição e companheirismo, ela também é atravessada por divergências e implicâncias. A irmã do meio, Ana, por exemplo, contou que frequentemente as meninas brigavam entre si. 
"E brigam pelo quê?", eu perguntei em determinado momento. Ana: "Ah, por tudo, tia! Mas principalmente porque a Danielle é folgada e chata!" Eu: "Como assim 'folgada e chata'?"; Ana: "Ah, ela acha que pode tudo em casa, faz bagunça e fica implicando comigo e com a Adrielly. Aí eu xingo ela dizendo que ela tem que parar e ela vem e dá coça em mim". Eu: "E o que é 'dar coça', Ana?" Ana: "Ela vem me bater." Eu: "E o que vocêfaz?" Ana: "Brigo com ela e conto pra mamãe! Aí depois ela vem dizer que me ama, só porque levou coça da mamãe também". (Diário de Campo, Novembro de 2015)

Na situação em que Danielle é implicante, Ana não a poupou, pois contou à sua mãe sobre a briga para que a irmã fosse punida. É possível afirmar que as expressões, ora de empatia e cuidado, ora de desagrado e provocação, não são excludentes e sim, qualificam juntamente a relação dessas irmãs. O fato de Ana mencionar a "coça" em associação seguida ao "amor", que a irmã declara sentir por ela, corrobora para esta junção ambígua e, ao mesmo tempo, complementar que a relação entre elas expõe. Assim, vemos que a qualidade da relação entre as crianças cuidadas e as crianças cuidadoras muda frequente e repentinamente ao longo de suas interações, e também é perpassada por brigas, conflitos e rivalidades (Colonna, 2012).

Faz-se necessário ressaltar que trouxemos nesta seção apenas experiências de cuidado entre irmãs, não sendo contempladas neste estudo relações entre meninos. A existência de relações de cuidado entre irmãos se apresentou em algumas situações na escola, mas não se destacaram. Punch (2001) aponta que o gênero representa um dos múltiplos fatores que condiciona a divisão das atividades domésticas infantis realizadas em casa, e outros estudos nos dizem que as meninas são mais propensas a assumirem a posição de cuidadoras dos/as irmãos/ãs do que os meninos (Cicirelli, 1994; Soares, 2009).

5.2 “Gosto de arrumar a casa pra fazer uma surpresa pra minha mãe!": as contribuições das crianças no ambiente doméstico 
As crianças no encontro com o outro: uma perspectiva relacional e afetiva da responsabilidade

No dia a dia da maioria das crianças de quem nos aproximamos, a realização de atividades domésticas era muito comum. Ainda que as práticas variassem de criança para criança, é possível nomear, de acordo com as suas falas, que as mais novas, de 5 a 8 anos, realizavam atividades como arrumar os seus brinquedos, o seu material escolar, guardar a sua roupa e arrumar as suas camas. Já as mais velhas, de 9 a 12 anos, realizavam atividades que iam desde arrumar os seus próprios pertences a cozinhar, lavar banheiros, o chão, o quintal de suas casas, fazer compras e ajudar a mãe em seu trabalho.

$\mathrm{Na}$ fala de algumas crianças foi possível apreender que a realização destas atividades era entendida como algo natural em seus cotidianos. Isto é, as atividades domésticas faziam parte da rotina de algumas das crianças e eram vistas como normais no âmbito de suas famílias, assim como foi constatado em outras pesquisas (Punch, 2001; Morrow, 2008; Colonna, 2012; Pires, 2012). Ao justificarem essas práticas e/ou dizerem como se sentiam as praticando, elas apontavam a ajuda familiar e a felicidade parental como associações importantes em relação a elas. Nos extratos a seguir, evidenciamos algumas considerações sobre isso:

Yasmim, Isabelle e eu andávamos conversando na rua e quando nos aproximávamos da casa de Isabelle, Yasmim perguntou:

- Yasmim: Belle, você vai lá no centro [da cidade] hoje?

- Isabelle: Hoje não vou não, porque eu vou limpar o quintal e os banheiros que não limpei no Domingo.

- Yasmim: Putz, sério!?

- Isabelle: Pois é, no domingo eu fiquei com preguiça, aí vou ter que limpar hoje.

- Eu: E como é isso, Isabelle, de você limpar o quintal e os banheiros? É comum?

- Isabelle: Ih tia. É sim! Sabe tomar banho todo o dia? Então, é igual a passar vassoura na casa! (risos)

- Eu: Ah... (risos) E o que você acha disso?

- Isabelle: De arrumar a casa? Olha, você pode me achar maluca, mas eu gosto de arrumar a casa. Até porque aqui [já estávamos em seu portão], cada um faz uma coisa, sabe? Os meus pais trabalham fora e a minha tia também, então geralmente a minha avó cozinha e eu e Carol 
[prima que mora no mesmo quintal] limpamos a casa... É uma maneira de ajudar, né? A gente fica em casa o dia todo e a minha avó já está ficando velha. Cada uma ajuda um pouco e no final a casa fica um 'brinco' (risos). (Diário de Campo, Novembro, 2015)

Para a menina, que faz a associação entre tomar banho e passar a vassoura na casa como práticas que ela realiza diariamente, arrumar a casa é uma forma de ajudar a família. A sua fala aponta também para a consideração de que em sua casa, cada membro familiar contribui de alguma maneira para a manutenção do lar e, nesse sentido, ela se inclui como contribuinte. Ressalta-se também a consideração que ela faz em relação à geração mais velha da família, representada por sua avó. A menina evidencia o fato de sua avó já ser idosa e, nesse sentido, também precisar de ajuda.

Em uma ocasião em que eu conversava com Ana, de 8 anos, na escola, a menina apontou que, na ausência dos pais, era ela e suas irmãs que cuidavam de si próprias, como uma forma de também deixar a sua mãe feliz:

Neste dia, Ana me disse que não quis comer porque tinha abóbora no almoço da escola e não gostava deste legume. Eu perguntei, então, se em casa ela também não comia quando não gostava da comida e a menina me respondeu que em muitas vezes ela que cozinhava o que ela gostava, como "miojo, ovo, arroz". Em seguida, completou: "Mas lá em casa eu não só cozinho não, tia. Eu adoro limpar o chão, deixar a casa brilhando". Eu a indaguei sobre isso e ela justificou: "Porque eu gosto de ver tudo brilhando, tudo branquinho... Gosto de arrumar a casa pra fazer uma surpresa pra minha mãe!"; "Ah, como assim 'surpresa', Ana?", perguntei. "É porque ela trabalha muito e às vezes não tem tempo de cuidar nem da gente". Eu questionei: "Se ela não tem tempo, então quem cuida?"; Ana: "O meu tio de mais ou menos [padrasto]. Eu: "O seu padrasto?"; Ana: "É, mas às vezes ele também está na venda e não pode cuidar". "Aí quem cuida?", perguntei novamente; Ela respondeu: "A gente mesmo!", com um sorriso no rosto, 
As crianças no encontro com o outro: uma perspectiva relacional e afetiva da responsabilidade

como se estivesse orgulhosa por isso. "E como vocês cuidam de si mesmas?"; Ela: "Fazendo as coisas em casa... Tipo, a comida, nosso dever da escola, limpando a casa e não brigando uma com a outra". Eu: "E por que vocês fazem essas coisas?" Ela me respondeu: "Porque a mamãe não tem tempo, aí ela fica feliz quando a gente faz as coisas direito e não briga." (Diário de Campo, Dezembro, 2015).

O extrato acima nos mostra que a menina Ana realiza certas atividades em casa, como limpar a casa, deixando o chão limpo, porque gosta de fazer uma surpresa para a sua mãe que teria pouco tempo para se dedicar a estas tarefas. Além disso, vemos que, na ausência dos adultos da família, é as próprias meninas que "cuidam de si", o que, segundo ela, concretiza- se nas práticas de preparar a própria comida, fazer o dever da escola, limpar a casa e manter uma boa relação com as irmãs. A justificativa para a realização dessas práticas decorre de um sentimento gerado em sua mãe, de "ficar feliz", pela percepção de que as meninas estão cuidando de si.

Para o menino Michel, de 10 anos, que vai a padaria com frequência comprar comida a pedido da mãe, esta atividade também é realizada em associação ao que sente um membro de sua família, neste caso, o seu pai:

Eu conversava com o Michel, que estava sentado no banquinho do pátio segurando um bolo para a festa na escola. Ele me disse que a sua mãe que tinha feito o bolo, mas que havia sido ele que comprara os ingredientes na padaria próxima da sua casa.

Eu: E Michel, você foi à padaria só porque teria a festa hoje ou você costuma ir nela mais vezes sem nenhum adulto?

Michel: Ih tia, eu vou direto! Volta e meia a minha mãe esquece alguma coisa do mercado e pede pra eu ir lá.

Eu: E o que você acha de ir lá quando a sua mãe te pede?

Michel: Normal, eu vou lá direto, já conheço todo mundo. Aí depois o Sr José, o dono da padaria, fala pro meu pai como eu sou educado e comprei tudo direitinho. Eu: Ah é? E o que que tem o Sr. José falar isso de você? 
Michel: Ah tia, o que tem que é bom, porque meu pai fica todo feliz, orgulhoso de mim, em seguida o menino abre um sorriso. (Diário de Campo, Dezembro de 2015)

Vemos que para o Michel ir a padaria é uma atividade que ele considera "normal". Em seguida, em sua fala, destaca-se as atribuições positivas realizadas pelo dono da padaria sobre ele e como elas têm um impacto relevante, uma vez que ressoam sobre como se sentirá o seu pai. Para o menino, deixar o pai "feliz" e "orgulhoso" é importante e o faz se sentir bem por isso.

\subsection{A "tia" que não é daqui e pode se machucar ou se perder: o cuidado com a pesquisadora do trabalho de campo}

Um dos aspectos da rotina das crianças que constatamos é que muitas delas realizavam o trajeto de suas casas até a escola e vice versa sem a companhia de nenhum adulto. Muitas delas iam em companhia de seus/suas irmãos/ãs, como já relatamos, e outras também com seus grupos de pares ou sozinhas. Ao me aproximar das crianças e estabelecer uma relação mais consolidada com elas, eu acabei sendo convidada para acompanhá-las em seus trajetos e também me inserir nos grupos que percorriam as ladeiras da comunidade em que moravam.

Yasmim, aluna do $6^{0}$ ano de 12 anos, foi uma das crianças de quem mais me aproximei. $\mathrm{O}$ nosso contato foi estabelecido, principalmente, através da brincadeira do Queimado. Yasmim jogava muito bem este jogo e era quem, frequentemente, acertava mais bolas em outras pessoas. No início da minha inserção nesta brincadeira, por anunciar que eu não tinha certeza das regras e ser nomeada como café com leite ${ }^{5}$, ela disse, então, para eu não me "preocupar", pois ela iria me "proteger". Eu, curiosa com a fala dela, perguntei: "Me proteger? E eu preciso ser protegida?". E ela me respondeu: "Claro, né tia? Você não joga bem ainda!". Diante da fala dela e curiosa com a sua postura, eu concordei que ela, então, me protegesse no jogo.

5 Expressão usada pelas crianças me identificarem como alguém que estava participando com certa "neutralidade" do jogo, não podendo ser alvo de bolas fortes. 
As crianças no encontro com o outro: uma perspectiva relacional e afetiva da responsabilidade

De fato, ao longo das minhas primeiras participações no Queimado com a turma do $6^{\circ}$ ano, foi assim que ela se posicionou perante a mim, pegando a maioria das bolas que alguém tacava em minha direção e tentando evitar que me queimassem. A sua posição protetora para comigo não se limitou, entretanto, nas brincadeiras do Queimado. Ela se manifestou, principalmente, durante os trajetos percorridos pelos arredores da comunidade onde se localizava a escola.

Neste dia, eu fui acompanhar as meninas do $6^{-}$ano pela primeira vez em direção às suas casas, pelo caminho que dá na estação de trem Central do Brasil, que normalmente é mais movimentada. Estávamos andando e conversando já com o grupo diminuído quando, ao atravessar uma rua onde passava carros, Yasmim pegou no meu braço, puxando-o e disse em tom firme: "Tia, você quer morrer?!!". Eu, assustada com a atitude repentina, pedi então que me explicasse. Ela respondeu: "Ué, você não viu o carro passando? Ele estava vindo muito rápido, você pode se machucar se andar devagar assim!" Carol que estava conosco, comentou rindo: "Yasmim, a tia não é daqui, você não sabe? Ela é rica, é quase estrangeira, não sabe andar por aqui!". Eu: Como assim 'eu sou rica e estrangeira' e por isso eu não sei andar por aqui? E Carol me disse: "Tia, aqui você não pode dar mole, achar que está passeando. Tem que ficar ligada, pra não correr perigo, entendeu?" Eu, então, respondi: "Entendi... Mas que tipo de perigo você está se referindo?". Ela: Ah tia, muitos! É só não dar bobeira!! Em seguida, a menina se despediu, pois tinha que pegar outra rua para a sua casa. [...] (Diário de Campo, Setembro de 2015).

Neste episódio descrito, Yasmim puxou o meu braço para impedir que eu fosse atingida por um carro que vinha na rua em que atravessávamos, apesar desse perigo não ter sido constatado por mim. $\mathrm{O}$ fato de eu estar andando devagar foi associado pela menina Carol a eu ser "rica, quase uma estrangeira" e estas se apresentarem como condições para eu não saber andar pela região. Apesar de estes adjetivos serem comumente 
utilizados em nossa sociedade como definidores de status e poder, no contexto em que estávamos eles foram usados pela menina Carol para apontar a diferença que eu expunha em relação às pessoas que moravam na região e, portanto, saberiam andar por ali sem "dar mole" ou "achar que está passeando".

Na sequencia desta situação, eu fui conversando com Yasmim sobre a comunidade e sobre o que ela entendia pelos "perigos" dali. Para chegar à estação de trem, onde eu pegaria o metrô pra ir embora, e ela o teleférico para subir a outra comunidade que morava, nós tínhamos duas possibilidades: a de passar pela rua de acesso principal atrás da estação, ocupada por muitos moradores de rua e também usuários de drogas, ou darmos uma volta muito grande para chegarmos à sua frente. Diante de suas colocações sobre a região, eu perguntei, então, a sua opinião: "O que você acha, Yasmim? É seguro passar pela rua ou é melhor darmos a volta?" e ela me respondeu, com toda firmeza: "Olha, tia, seguro não é. Mas nunca me aconteceu nada e estando comigo, por eu estar com o uniforme da escola, também não vai ser hoje que vai acontecer! É só a gente continuar conversando e andar rápido, só isso!".

Yasmim, naquele momento, apresentava para mim que não estava segura quanto a sua opinião, em contrapartida, decidiu assumir a sua escolha e arriscá-la mesmo assim, sugerindo que continuássemos o percurso. $\mathrm{O}$ fato de ela associar o seu uniforme da escola como um "amuleto", algo que poderia nos proteger, chamou a minha atenção. Neste caso, o fato de ser estudante tem um valor social naquela região e parece ser algo que as resguardaria em determinadas situações. Eu, por estar em sua companhia, então, também seria protegida por esse valor que o uniforme possui.

Também na ocasião em que Yasmim me convidou para ir almoçar em sua casa e conhecer a sua família, a menina demonstrou o quanto conhecia sobre a região e também a sua preocupação para que eu ficasse "ligada" as situações que ocorriam ao nosso redor. Durante o trajeto, na ocasião em que chegávamos perto da ruela onde se localizava a casa de sua mãe, bem na esquina, deparamo-nos com dois jovens sem camisas com pistolas presas em suas bermudas. Ao avistá-los a uns dois metros de distância, a menina olhou pra mim e disse em tom baixo: "Só cumprimenta, tia. Só cumprimenta!". Em seguida, passamos por eles, demos "boa tarde!" e seguimos o caminho. Em momento posterior, ela me contou que aqueles 
As crianças no encontro com o outro: uma perspectiva relacional e afetiva da responsabilidade

eram "meninos do tráfico" e não gostava deles, porque os considerava "bandidos" que a deixavam com "medo".

A grande maioria das comunidades de baixa renda do Rio de Janeiro é dominada por grupos de traficantes de drogas e armas ou por milícias que se impõem ditando regras e impedindo a livre circulação das pessoas. Nesses casos, somente alguns sujeitos podem ter acesso a determinadas regiões, outras devem manter a distância sob o risco de colocarem a própria vida em jogo (Castro et Pérez, 2011).

Durante este dia, Yasmim não quis falar sobre o tráfico de drogas que ocorria na esquina da casa da sua mãe ou sobre os meninos que atuavam nele, mas foi possível apreender que, mesmo ela se sentindo com medo e insegura, não se sentia impedida de percorrer os seus trajetos e enfrentar os dilemas que eram lhe apresentados.

A partir desta aproximação do cotidiano de Yasmim, vimos que ela conhecia muitas das ruas da região, as pessoas, os pontos principais; sabia como nós deveríamos nos posicionar para estar ali, dando-me conselhos ou agindo em prol da minha segurança. Yasmim possuía conhecimentos para lidar com aquilo que não considerava "seguro" e que diziam respeito à vida prática em sua comunidade, situações apreendidas a partir da vivência de seu próprio cotidiano.

Estes exemplos trazidos nos apontam, em primeiro lugar, que algumas crianças das quais nos aproximamos se apropriam dos espaços das comunidades onde vivem, fisicamente e afetivamente. As crianças e jovens se apropriam simbolicamente da cidade a partir de sua participação naquele espaço, de histórias e lembranças de situações vividas ali (Castro et Pérez, 2011).

Na contramão de se protegerem do medo e dos perigos que a vida na cidade pode proporcionar, isolando-se em lugares privados e supostamente seguros como normalmente faz a classe média e alta, as meninas identificam os possíveis perigos que as cercam pelas ruas de suas comunidades e também criam modos de lidar com eles. $\mathrm{O}$ fato de morarem em lugares, cujos perigos concretos atravessam as suas vidas diariamente em maior grau e frequência do que em outros lugares da cidade, não as impede de circular com confiança em si próprias, e também de se sentirem em casa, dominando os espaços que transitam.

Chama atenção também que essa ambientação que as faz "se sentirem em casa na rua" (Idem, p. 114) não é limitada pelo fato de serem 
crianças. A idade parece não ter sido determinante das percepções das crianças a meu respeito. $\mathrm{O}$ fato de eu ser adulta não foi condição para eu que fosse vista por elas como alguém auto suficiente naquela região, mesmo eu sendo uma "tia, rica e estrangeira", na visão de uma das meninas.

Ao me aproximar das crianças na escola e acompanhá-las durante os seus percursos pelas comunidades, eu me apresentei para elas como alguém que precisava de ajuda, ora porque não sabia jogar a brincadeira do Queimado ainda, ora porque não era moradora da região e, portanto, precisava aprender a me portar diante de determinadas situações, e também a conhecer melhor as ruas para não me machucar ou me perder. Eu era uma pessoa que, naquele contexto, mostrava-se vulnerável e frágil diante das meninas.

Nesse sentido, no encontro comigo, quem se apresentava vulnerável e frágil não eram as crianças, como se poderia esperar, já que são estes atributos que qualificam em grande medida a literatura que aborda a especificidade da criança. Ao contrário, a convocação para uma ajuda partia de uma adulta que, supostamente, por seu lugar de escolarização, renda, moradia e idade, seria mais empoderada. Tal convocação não foi realizada verbalmente, pois eu não disse às meninas que eu precisava de auxílio e/ou esta percepção foi anunciada por alguém. As suas manifestações de proteção e cuidado comigo se deram espontaneamente a partir das experiências partilhadas entre nós.

Nós destacamos também, que a minha interação com as crianças se deu de forma muito prazerosa e afetuosa, aspectos que pareceram determinantes na sua maneira de agir nas situações em que eu lhes pareci vulnerável e precisando de ajuda. Acreditamos que o vínculo estabelecido entre nós anteriormente tenha influenciado o modo de se posicionaram perante a mim nas situações de cuidado, o que levanta a questão de como agiriam se a relação não fosse mediada por afetos tão positivos. .

\subsection{Os pares que precisam de ajuda na escola: brincadeiras infantis e amigos com necessidades especiais}

A nossa aproximação ao cotidiano infantil também nos permitiu apreender a responsabilidade pelo outro nas relações das crianças com seus pares. Como já exposto anteriormente, uma das formas de eu me integrar com as crianças foi através das brincadeiras. Eu passava praticamente todo 
As crianças no encontro com o outro: uma perspectiva relacional e afetiva da responsabilidade

o horário do recreio brincando e conversando com elas e, durante estes momentos, nós pudemos observar muitos aspectos de cuidado, cooperação, interação entre as próprias crianças.

No tempo institucional de vinte minutos destinado ao recreio, raramente eu via alguma criança solitária ou brincando sozinha. Ao contrário, estavam na maioria das vezes com outras crianças, em grupos grandes ou mais reduzidos, como em duplas e trios. Observamos que as crianças que brincavam juntas eram normalmente da mesma turma, mas nem sempre. Como destacado no extrato abaixo, a aproximação de uma pessoa nova na brincadeira que não sabia brincar era motivo de aprendizado e troca entre algumas crianças:

Neste dia eu brincava com três meninas do $2^{\underline{\underline{o}}}$ ano de pular corda, que eram amigas que sempre estavam juntas na hora do recreio. Eu e mais uma das meninas rodávamos a corda, enquanto as outras duas se revezavam em pular ou pulavam juntas. Em determinado momento, duas outras meninas, de turma diferente, aproximaram-se e perguntaram para mim se poderiam brincar conosco. Eu disse que sim, olhei para as outras meninas que já brincavam anteriormente, elas cochicharam entre si e disseram que sim também. Quando chegou a vez de uma das meninas novas, em sua primeira tentativa, ela se embaralhou e não conseguiu pular a corda. Amanda, que batia a corda junto comigo, disse: "Mais uma vez, tenta!". Mais uma vez, então, nós rodamos a corda e a mesma ficou parada na canela da menina, que pulou sim, muitas vezes, mas no momento em que a corda já tinha encostado nela. Uma das meninas que aguardava a sua vez de pular, a Bruna, disse: "Você não sabe pular corda, né?" E a menina não respondeu, apenas ouviu o comentário, com uma feição de constrangimento. Então, Bruna completou: "Não tem problema! Aqui ninguém sabia também... Tenta mais uma vez!". Eu, observando o desenrolar desta situação, rodei a corda mais uma vez com Amanda. E, novamente, a corda parou nas pernas da menina. Nesse momento, Bruna foi ao seu encontro, no centro da corda, pegou a 
sua mão e disse: "Olha, é o seguinte, a gente já sabe pular, você não. Então presta atenção como eu pulo primeiro e depois é a sua vez de novo". Bruna, então, pediu que Amanda e eu rodássemos a corda. Ela pulou, muitas vezes. E, depois, ao parar de pular, voltou-se para a menina e disse: "Entendeu? Agora é a sua vez!" Novamente, a menina não conseguiu, mesmo tentando algumas vezes. Em determinado momento, quando um constrangimento da menina se tornava aparente novamente, Bruna se aproximou e disse: "Pular corda é fácil, mas é difícil também. É melhor a gente pedir pro Tio Vicente uma corda menor porque aí você consegue treinar". [...] (Diário de Campo, Outubro de 2015)

Esse extrato acima nos aponta aspectos da interação das meninas que já sabiam brincar de pular corda com uma menina que não sabia, de uma turma diferente. No desenrolar da cena, vemos, primeiramente, que Bruna é a menina que assume a liderança desta interação. No momento em que a menina nova na brincadeira se mostra constrangida por não conseguir pular a corda, Bruna constata este fato e acolhe o seu embaraço dizendo que "não tem problema", já que ali naquele grupo, em algum momento anterior em suas vidas, as meninas também não sabiam brincar de pular corda. Nesse sentido, a menina afirmou que o conhecimento que tinha acerca da brincadeira não era "seu", essencialmente.

Neste extrato também observamos que Bruna se sensibiliza com o fato da menina estar ficando constrangida novamente na brincadeira, por não ter conseguido pular mesmo após muitas tentativas. Quanto a isso, parece-nos que Bruna reconhece a dificuldade e o embaraço em que a outra menina se encontra, e admite a própria dificuldade da brincadeira que, para ela, já é fácil, mas ao mesmo tempo, é difícil para quem não sabe ainda. Desse modo, Bruna parece ter se sentido convocada a ajudar outra menina que não conseguia brincar e, como solução, propõe a própria prática da brincadeira, pois só na tentativa e no erro que ela poderia, finalmente, aprender.

Sobre a interação que as crianças produzem durante as brincadeiras infantis, destaca- se o que Borba (2005) aponta nos resultados de seu estudo realizado em uma unidade municipal de educação infantil. Ela nos diz que 
As crianças no encontro com o outro: uma perspectiva relacional e afetiva da responsabilidade

através de experiências conjuntas, das posições que as crianças assumem junto aos/as companheiros/as, pelos papéis que adotam nas brincadeiras com os outros, bem como pelas ações que desenvolvem associadas às diferentes brincadeiras das quais participam, as crianças vão construindo e estruturando as suas relações sociais, as regras de sociabilidade e seus vínculos afetivos. Em suas palavras, o "desejo de brincar junto move a criança em direção ao outro" (Idem, p. 157).

Para nós, esta constatação corrobora o que eu vivenciei com as crianças em nosso estudo durante os momentos em que as observei brincando ou participei de suas brincadeiras. Ir em direção ao outro assumiu, literalmente, as cenas das crianças correndo ou se reunindo no pátio para brincar e, sobretudo, significou a construção de laços e vínculos afetivos, assim como demonstrações de cooperação, cuidado e reciprocidade entre os sujeitos que brincavam juntamente.

Vimos também que o cuidado entre as crianças e seus pares manifestado nas brincadeiras também se estendeu para outros momentos de interação entre elas. A escola que nos inserimos era contemplada com um programa de inclusão escolar, em que um profissional especializado em Educação Especial orientava e acompanhava o trabalho de alunos e alunas com necessidades específicas junto a classes de ensino regular. Durante a minha inserção, eu pude me aproximar do trabalho de um jovem profissional, que acompanhava as aulas junto com um aluno inserido neste programa. No entanto, a escola possuía outros alunos e alunas com necessidade específicas, que nem sempre possuíam este suporte, como o caso do Mateus.

Mateus era um menino de 10 anos, que estava no $4^{\circ}$ ano, e possuía, segundo a coordenadora, um "déficit neurológico". A coordenadora não soube me explicar ao certo o seu entendimento sobre esse déficit, mas apontou especificidades em sua fala e locomoção, além de dificuldades de aprendizagem. A primeira vez que o vi na escola foi em uma situação em que um grupo de cinco meninos estava jogando bola entre si e Mateus chegou andando, com um pouco de dificuldade, para se juntar ao grupo. Eu os observei de longe e vi que o menino foi bem recebido e o restante do grupo compartilhava bolas com ele. Mateus dominava a bola e a tacava de volta aos colegas com certo sacrifício. Depois de algumas tentativas de direcionar o seu lance, o menino se separou deste grupo e foi brincar sozinho, com outra bola. 
Mateus brincava com a bola sozinho e depois de alguns minutos, Fernanda, de 9 anos, aproximou-se dele. Nesta ocasião, eu ainda não conhecia a Fernanda e observei a interação dos dois, que passaram a brincar juntos. Eu notei que Fernanda era muito paciente, pois o menino tacava as bolas com frequência a uma distancia bem grande dela, fazendo com que ela fosse até onde a bola estava para buscá-la e em seguida tacava para ele novamente. Em determinado momento, os dois pararam de brincar e Mateus foi em direção ao bebedouro. A menina foi atrás. Os dois beberam água e logo depois, ela foi até uma mochila próxima, pegou uma toalha de rosto e começou a passar com delicadeza ao redor da boca e do pescoço do menino, que havia se molhado bastante com a água. Na sequencia, o sinal do recreio tocou e as outras crianças saíram correndo para formar a fila para subir. Nem Fernanda, nem o Mateus saíram correndo. A menina pegou a mochila, que, na verdade, era dele, colocou em suas costas, os dois deram as mãos e, mesmo a fila da sua turma já tendo subido, os dois foram andando devagar atrás.

No dia seguinte, na hora do recreio, eu avistei a Fernanda, mas Mateus não estava, pois havia faltado. Em determinada situação, quando ela estava mais próxima de mim, eu comecei a conversar com ela e, curiosa com a interação do dia anterior, lhe fiz algumas perguntas após uma apresentação inicial de ambas as partes.

[...] E Fernanda, ontem eu te vi brincando com o Mateus, ele é seu amigo?

Fernanda: É, sim!

Eu: Eu também te vi ajudando ele a não se molhar com a água e o acompanhando na hora de subir, você costuma fazer isso sempre?

Fernanda: Aham, porque nem sempre ele tem alguém que pode ajudar e ele confia em mim.

Eu: Como assim ele confia em você?

Fernanda: Ah, é porque na sala acho que eu sou a única amiga dele. No início do ano, ele não falava com ninguém, aí só falava comigo.

Eu: Ah é? E por que você acha que você é a única amiga dele? 
As crianças no encontro com o outro: uma perspectiva relacional e afetiva da responsabilidade

Fernanda: Porque ele gosta de mim e fala pouco com as outras pessoas, aí eu ajudo ele com as tarefas na sala e aqui no pátio.

Eu: Ah, entendi... E você gosta de ajuda-lo?

Fernanda: Gosto, porque ele precisa de ajuda, não faz tudo sozinho, aí a tia deixa eu cuidar dele.

Eu: E foi a tia que pediu pra você cuidar dele?

Fernanda: Não, eu que cuido mesmo... Lá em casa eu tomo conta de uma bebê bem pequeninha, aí gosto de cuidar do Mateus também.

Eu: A bebê é da sua família?

Fernanda: Não, uma moça paga a minha mãe pra tomar conta dela, mas sou eu que cuido dela, dou comidinha, seguro ela no colo, pego ela na casa dela...

Eu: E cuidar da bebezinha é igual ou diferente de cuidar do Mateus?

Fernanda: É diferente! Ela chora o tempo todo (risos), o Mateus não, a gente brinca junto. (Diário de Campo, Outubro de 2015).

Nas descrições acima, nós destacamos alguns aspectos da interação da Fernanda com o Mateus que dizem respeito a como a menina se posiciona diante das necessidades do menino. Vimos que Fernanda, além de brincar com ele na hora do recreio, também costuma ajuda-lo para não se molhar com a água assim como na sala de aula, com as tarefas dadas pela professora. A menina destaca que, na ausência de alguém para ajudalo, como seria o caso do profissional em Educação Especial, é ela quem assume o cuidado para com ele.

A sua justificativa passa pelo sentimento de confiança que o menino teria com ela, e o fato de ela achar que é a única amiga dele, pois interage mais com ela do que com outras crianças. Além disso, Fernanda diz gostar de ajuda-lo porque o menino necessitaria de ajuda e não faz tudo sozinho. Isto é, aprecia esta prática, pois sente que assim o estaria ajudando.

Nós ressaltamos também o fato deste cuidado direcionado ao Mateus ser tomado com naturalidade pela menina e ocorrer a partir de uma iniciativa própria, não partindo de um direcionamento da professora ou de outro adulto da escola. Acrescentamos que, mesmo não sendo uma tarefa 
delegada por um adulto, é possível sugerir que o fato da professora saber e permitir o seu cuidado para com o Mateus pode dar a menina algum lugar de reconhecimento e valor perante a sua turma.

$\mathrm{Na}$ sequencia, vemos que a menina associa o cuidado para com o Mateus ao cuidado que possui com uma bebê, que passa as tardes em sua casa. A menina conta que toma conta da criança mais nova, buscando-a em sua casa, segurando-a em seu colo e dando comida a ela. Ainda que estas sejam atividades que a sua mãe estaria comprometida a executar, uma vez que fazem parte de seu trabalho, a menina também participa e contribui com essas tarefas. O fato de já executá-las em casa pode favorecer para que Fernanda assuma a ajuda para com o Mateus com naturalidade e tranquilidade na escola, como evidenciado.

Por fim, chamou a nossa atenção a associação que a menina faz do cuidado com o Mateus à brincadeira, diferentemente do cuidado com a bebê mais nova. Ao inserir esta diferença, Fernanda parece valorar positivamente o fato de brincar com o menino e, nesse sentido, apesar de identifica-lo como alguém que "precisa de ajuda", ela também associa o brincar ao estar "junto", que realça o aspecto da interação e união que este cuidado parece significar para ela.

\section{Considerações Finais}

As análises propostas acima a partir do que as crianças vivenciaram e disseram sobre seus cotidianos parecem revelar que as crianças são sujeitos responsáveis pelo outro que as interpela a partir de uma demanda cuja resposta exige uma experiência heteronômica de afetividade. A noção de responsabilidade inspirada pela perspectiva ética de Emmanuel Levinas aproxima-nos do cotidiano das crianças, marcado pela presença não de indivíduos auto suficientes, cuja racionalidade e competência são os predicados de suas posições no mundo, mas de subjetividades descentradas, que se constituem por experiências de afetividades e por uma disposição em direção a alteridade (Critchley, 2008).

Os nossos resultados apresentaram que, ao contrário de ações plenamente autônomas e internalizadas como um cumprimento de deveres a partir da delegação adulta, as ações das crianças eram desencadeadas pelas relações sociais cuja afetividade exercia papel significativo, sobretudo, quando mobilizavam as crianças acerca do suposto apelo e 
As crianças no encontro com o outro: uma perspectiva relacional e afetiva da responsabilidade

necessidade do outro. Tais relações podem ser compreendidas como, por excelência, parciais, mutáveis, distendidas e assimétricas (Molinier et Papermann, 2015), uma vez que eram perpassadas por uma inadequação própria da experiência intersubjetiva, na qual as crianças puderam se posicionar de diferentes formas a cada novo encontro com o outro.

A partir dos exemplos trazidos, foi possível apreender primeiramente que as crianças desta comunidade pesquisada demonstram cuidado e proteção por pessoas com quem possuem algum grau de filiação e parentesco. No caso das relações entre irmãs, as crianças apontam a afeição, a solidariedade, a empatia e o parentesco como justificativas para que as suas irmãs não se machuquem, não sejam castigadas e/ou não se entristeçam. As relações fraternas também são atravessadas por disputas e chateações entre as crianças, revelando que as suas relações são flexíveis e negociadas entre si.

Muitas delas também se envolvem ativamente na manutenção de seus lares, através de atividades domésticas, como arrumar a casa, lavar o chão, entre outros, que são entendidas no âmbito de suas famílias como práticas naturais de serem realizadas pelas crianças. Essas atividades domésticas, assim como os cuidados entre as irmãs, são perpassadas pelas ideias de ajuda familiar e felicidade parental, revelando que o que sentem/pensam suas mães, pais e irmãs são importantes para elas e o quanto a filiação, a interdependência e a reciprocidade estão presentes no âmbito destas relações.

Entretanto, não apenas o outro posicionado como um membro familiar convoca às crianças a se posicionarem como sujeitos responsáveis. Vimos que a pesquisadora do trabalho de campo e os pares das crianças se apresentaram como esse outro que também as interpelava em direção a uma posição responsável.

O posicionamento cuidadoso das crianças para com a pesquisadora nos mostrou que o fato de elas serem mais novas e a pesquisadora uma adulta não foi determinante para que a vissem como alguém que não precisasse de ajuda. A condição de não ser moradora das comunidades onde as crianças habitavam e, portanto, não conhecer bem os lugares e como se portar em determinadas situações aparentemente de risco e perigo, fez com que a vissem como alguém vulnerável e frágil diante delas.

De forma semelhante, no encontro de algumas crianças com seus pares nas experiências das brincadeiras infantis, nós vimos que algumas 
delas se posicionaram de forma cuidadosa com aqueles que as interpelaram por suas dificuldades e necessidades. As crianças, assim como a pesquisadora, não declararam verbalmente que precisavam de ajuda. Esta percepção delas advém do que elas vivenciaram na experiência relacional com essas pessoas.

Faz-se necessário ressaltar que, ainda que nem a pesquisadora e nem os colegas das crianças fossem um membro efetivo de suas famílias, de alguma maneira, eles eram familiares a elas, pois tinham vínculos afetivos estabelecidos e partilhavam momentos de interação. Nesse sentido, parece que o desafio é reconhecer as relações que ligam as crianças (e todos nós) a diversos outros e povos, separados no espaço e no tempo, e que não se conhecem. A nossa aposta, junto com Molinier et Papermann (2015) , é que se as relações particulares suscitam a responsabilidade compreendida na perspectiva relacional, então, a particularidade deve poder aceder a uma ética global.

Como nos dizem Molinier et Papermann (2015) não se trata de estender a responsabilidade às pessoas que estão à distância ou que não mantemos relações diretas e contínuas (Idem). Tratar-se-ia, para nós, de considerar e legitimar a existência das relações particulares, concretas e tudo aquilo que as atravessa.

Dessa forma, podemos nos perguntar se será mesmo pela via da reinvindicação de uma noção de responsabilidade como o cumprimento de uma obrigação a uma norma por um indivíduo infantil, que conseguiremos ressignificar o lugar social, ético e político das crianças hoje.

Em nosso trabalho, vimos que é justamente pela possibilidade de se deixar afetar pela interpelação que o outro faz, em relações mediadas pelos afetos positivos, que as crianças de nosso estudo contribuem para o entendimento de que a responsabilidade pode propiciar uma via de construção ético-moral alternativa para a convivência humana que não seja pelas regulações normativas e judiciais. Responder ao outro, posicionandose diante daquilo que interpela a criança afetivamente, é poder ser diante do outro e assim, admitir que é apenas com este outro que uma vida social se dá.

\section{Referências Bibliográficas}


As crianças no encontro com o outro: uma perspectiva relacional e afetiva da responsabilidade

BJERKE, Håvard. Children as 'differently equal'responsible beings: Norwegian children's views of responsibility. Childhood, v. 18, n. 1, p. 67-80, 2011.

BERTI, Silma Mendes. O Princípio e a Regra de Responsabilidade. Revista Brasileira de Estudos Políticos, v. 97, p. 339-360, 2008.

BORBA, Angela Meyer. Culturas da infância nos espaços-tempos do brincar. Tese (Doutorado em Educação) - Faculdade de Educação, Universidade Federal Fluminense, 2005.

BRAZ, Emerson; ANDRADE, Altamir Celio. A ética da alteridade em levinas: a lição do rosto do outro que clama por responsabilidade. RHEMA, v. 15, n. 48, 49, 50, p. 29-40, 2011.

BROBBEY, Charles. Children's Perspectives of their Responsibilities in Household Work in their Families in the Sekyere South District of Ghana. 2011. Master of Philosophy in Childhood Studies - Norwegian Centre for Child Research (NOSEB). Norwegian University of Trondheim, 2011.

CARREÑO, C. M.; ÁVILA, S. C. El vínculo de apego entre hermanos: un estudio exploratorio con niños colombianos de estrato bajo. Suma Psicológica, v. 9, n. 1, p. 107-132, 2002.

CASTANHEIRA, M. L. et al. Interactional ethnography: an aproach to studying the social construction of literate practices. Linguistics and Education, v.11, n.4, p. 353-400, 2001.

CASTRO L, R. Juventude e socialização política: atualizando o debate. Psic.: Teor. e Pesq., Brasília, v. 25, n. 4, Dec. 2009.

. Escrever sobre a infância, ter a infância dentro de si... In:

futuro da infância e outros escritos. Rio de Janeiro, 7 Letras, 2013.

CASTRO, L.R; BESSET, V.L (Org). Pesquisa-intervenção na infância e juventude. Rio de Janeiro. FAPERJ, 2008.

CASTRO, L. R.; PÉREZ, B. C. Jovens no Rio de Janeiro: percursos, inseguranças e riscos. Educação (UFSM), v. 36, n. 1, p. 107-120, 2011.

CAVALIERI FILHO, Sergio. Programa de responsabilidade civil. 9. ed. São Paulo: Malheiros, 2010.

COLONNA, Elena. "Eu é que fico com a minha irmã": vida quotidiana das crianças na periferia de Maputo. Tese (Doutorado em Estudos da Criança Especialidade em Sociologia da Infância) - Instituto de Educação, Universidade do Minho, Braga, 2012. 
CRITCHLEY, S; R. Demanding approval - a theory of ethical experience. In: Infinitely demanding: Ethics of commitment, politics of resistance. London: Verso Books, 2008, p. 14- 32.FLEKKØY, Målfrid Grude; KAUFMAN, Natalie Hevener. The participation rights of the child: Rights and responsibilities in family and society. Jessica Kingsley Publishers, 1997.

FARIAS, André. Por que a responsabilidade?Why responsibility? CONJECTURA: filosofia e educação, v. 17, n. 1, 2012.

GOLDMAN, M. Os tambores dos mortos e os tambores dos vivos. Etnografia, antropologia e política em Ilhéus, Bahia. Revista de Antropologia, v. 46, n. 2, p. 423-444, 2003.

JAMES, A. Ethnography in the study of children and childhood. In: ATKISON, P. The Handbook of ethnography, p. 246-257, 2001.

KEATING, Heather. Being responsible, becoming responsible and having responsibility thrust upon them: Constructing the 'responsibility'of children and parents. In: Responsibility, Law and the Family. Aldershot: Ashgate, p. 125144, 2008.

LÉVINAS, Emmanuel. Totalidade e infinito. Tradução: José Pinto Ribeiro. Lisboa: Edições 70, 1992, [1980].

MOLINIER, Pascale; PAPERMAN, Patricia. Revista Brasileira de Ciência Política, n18. p. 43-57, 2015.

MORROW, Virginia. Responsible children and children's responsibilities? Sibling caretaking and babysitting by school-age children. Responsibility, Law and the Family. Ashgate: Ashgate, p. 105-124, 2008.

PIRES, Flávia F. Crescendo em catingueira: criança, família e organização social no semiárido nordestino. Mana, v. 18, n. 3, p. 539-561, 2012.

PUNCH, Samantha. Household division of labour: generation, gender, age, birth order and sibling composition. Work, Employment and Society, v. 15, n 4, p. 803- 823, 2001.

PROUT, Alan; JAMES, Allison. A new paradigm for the sociology of childhood? Provenance, promise and problems. In: . Constructing and reconstructing childhood: Contemporary issues in the sociological study of childhood, 2015 [1997].

SUCH, Elizabeth; WALKER, Robert. Being responsible and responsible beings: Children's understanding of responsibility. Children $\mathcal{E}$ society, v. 18, n. 3, p. 231-242, 2004. 
As crianças no encontro com o outro: uma perspectiva relacional e afetiva da responsabilidade

QVORTRUP, J.Childhood matters: An introduction. In: Qvortrup J, Bardy M, Sgritta G and Wintersberger H (eds) Childhood Matters: Social Theory, Practice and Policies. Aldershot: Avebury, 1994. 